\title{
The Context of Recreational Sports for Women in Iran
}

\author{
${ }^{1}$ Elahe Saadatifard ${ }^{*},{ }^{2}$ Mohammad Javadipour, ${ }^{3}$ Habib Honari, ${ }^{4}$ Marjan Saffari, \\ ${ }^{1}$ Hossein Zareian \\ ${ }^{1}$ Department of Sport Management, Sport Sciences Research Institute, Tehran, Iran. ${ }^{2}$ Faculty of \\ Psychology and Education, Tehran University, Tehran, Iran. ${ }^{3}$ Department of Sport Management, Faculty \\ of Sport Sciences, Allameh Tabataba'i University, Tehran, Iran. ${ }^{4}$ Department of Physical Education, \\ Faculty of Humanities, Tarbiat Modares University, Tehran, Iran.
}

Submitted 30 August 2018; Accepted in final form 06 October 2018.

\begin{abstract}
Background. Given the importance of women and their role in society, women's recreational sports are considered as one of the major issues in the fields of sports and leisure. Objectives. This qualitative study, which was conducted using an exploratory approach, aims to determine the contextual conditions of Iranian women's recreational sports. Methods. The statistical population of the research consisted of all the experts who had practical and scientific expertise in the fields of recreational sports and women's sports is conducted with a method and was selected using Purposive Sampling and Snowball method. Data collection tools included interviews and note-taking processes. After conducting 17 interviews (with 16 elites and 1 Canon group), the researcher reached theoretical saturation and after the data collection procedure, the data was analyzed using MAXQDA10 software and Qualitative Content Analysis. Results. 1254 initial codes or open codes were extracted after the analysis. To further categorize the data, the codes and raw data were constantly compared based on the similarities and differences, and similar codes were placed under the same category. The initial categorization of codes yielded 51 sub-categories which were further categorized into 22 categories in the next step. The obtained concepts were divided into eight major categories (in stage of selective coding) which consisted of socio-cultural, fundamentals of Islam, political, economic, geographical environments and macro-management, media and advertisement, and sports facility issues. Conclusion. Considering the importance of recreational sports in women, a proper understanding of the context of recreational sports can help the sport managers to apply appropriate strategies to develop it and compensate for its backwardness.
\end{abstract}

KEY WORDS: Context, Gender, Leisure, Recreational Sports.

\section{INTRODUCTION}

Along with the changes in lifestyles in today's world, leisure has become a specific need for human societies. Leisure is an absence of pressure and any job commitment and a creative use of time which has three functional and fundamental aspects: Peace, Entertainment, and Progress. Leisure is an inner experience which leads to a feelings of refresh and recovery and lifts the spirit of the individuals (1). Leisure is not a job, it is an antidote to work life and it is important to improve the quality of life of people. This section aims to provide a proper opportunity for all people to choose their favorite and suitable activity from among a variety of recreational activities (2). Recreational Sports are one of the most popular types of recreational activities which people often take part in as active participants or spectators at one of its levels.

\footnotetext{
*. Corresponding Author:

Elahe Saadatifard, $\mathrm{PhD}$,

Zip Code: 1245456798 , Sport Sciences Research Institute, $5^{\text {th }}$ Alley, Miremad St, Motahari, St, Tehran, Iran.

E-mail: Saadatifard2020@gmail.com
} 
Considering their goals and effective roles in the quality of life in today's societies, recreational sports seek to maximize the access of individuals to appropriate forms of physical activity and their participation in them (3). In this regard, it is essential to plan a way to help the participants in experiencing and gaining appropriate results and thus provide a nearly equal condition for all people, in which they identify their needs and take measures to satisfy them. Experiencing success brings about growth and creates a sense of positive feeling toward oneself (4).

Including at least half of the world's population, women play important and central roles in societies. Various studies have emphasized the effective role of recreational sports in improving women's health $(4,5)$. Limitations that women face when participating in recreational sports include cultural and social limitations (6, 7), financial limitations (8), individual and professional limitations $(9,10)$, and structural and managerial limitations (9). In addition to various limitations in Iran, cultural and religious features of the community have complicated the conditions of women's sports (11), preventing the development of women's recreational activities in our country, and reducing the rate of women's participation in recreational sports; however, in other societies, it is changing and growing (12). On the other hand, considering the physical and psychological health of Iranian women, it is absolutely necessary that a special attention is directed toward their recreational sports.

In this respect, Muniz et al. (2014) believes that separate measures for men and women is necessary, since the majority of economic, demographic, and social differences reflect gender-based behavioral differences and the negative effects of marriage and childbearing on the participation in sports and cultural activities are observed mainly in women (13). Toffoletti et al. (2017) also took a new approach to study Muslim women's sport due to their special conditions (14). So far, various studies have investigated and explained the condition and requirements of women's recreational activities. Anaza and McDowell (2013) have introduced intrapersonal, interpersonal, and cultural constraints, as barriers limiting urban Nigerian women's participation in recreational sports activities (6). El-Gilany et al. (2011) identified lack of time, unavailability, and unsuitability of sports facilities as the most common obstacles to students' participation in sports at Mansoura University in Egypt and reported socioeconomic condition of the family, women's gender, and lack of membership in health clubs as the predictive factors of lack of movement (15). In his study, Atghaya (2007) mentioned issues such as lack of facilities for women, the cost of sports and health clubs, lack of knowledgeable and experienced female trainers, an absence of effective advertisement, and proper culture-building among women in the country regarding the importance of sports activities. Mutmani (2014) believes that authorities' lack of attention to women's sports, patriarchal culture, time, economic conditions, and investment in the development of women's sports facilities are the most important constraints (11).

It is worthy to mention that various studies from different perspectives have focused on women's recreational activities in Iran (11). However, to compensate for the backwardness in this regard, it is essential that we pay attention to the context of women's recreational sports. Context indicates the location of incidents or events associated with a phenomenon; therefore, it is a specific set of conditions that gather in a particular time and place to create a set of issues to which individuals respond via their actions/interactions (16). Here, context is considered a special condition that influences the effective strategies for the development of women's recreational sports. Thus, a contextual study addressing this issue in our country can help the decision-makers in this regard to provide and implement proper developmental solutions. In this research, considering the importance and necessity of recreational sports for Iranian Muslim females, the context of women's recreational activities was taken into account in order to develop it. The researcher sought to answer the critical question that what the context of the development of women's recreational ports in Iran is.

\section{MATERIALS AND METHODS}

Research Design. The present study is qualitative in terms of type, practical in terms of the results, and exploratory in terms of its purpose. It is qualitative in the sense that it deals with the study of phenomena in their natural environment and attempts to interpret them as people see them (17), qualitative description focuses on providing straight descriptions of 
events or perceptions of events or perception with low inference interpretation (18).

Participant. The statistical population of the research consisted of all the experts who had practical and scientific expertise in the fields of recreational sports and women's sport is conducted with a method. These knowledgeable experts have been active in various educational and research departments related to the subject of the present study and were divided into two categories of 1. Executive managers and specialists and experts (those who have had an experience in executive activities in sectors related to women's recreational activities); 2 . Faculty members and Ph.D. graduates (people who have studied women's recreational activities).

Instrument and Data Collection. In this research, Purposive Sampling and Snowball methods were used to select the sample. To conduct a targeted selection of the interviewees, first, the research team provided a list of competent people in the field of women's recreational sports. These people were selected due to the first-hand information they possessed in this field. Then, a call was made with each of the experts and the interview guide was sent to them before the interview After that, samples were selected by employing Snowball method, in which the interviewee introduced other people who were knowledgeable and experienced in this regard to participate in the study, if he or she knew any. Sampling continued until theoretical saturation occurred and new conceptual information was not obtained. To conduct this research, in total, 16 experts (female: $n=7$, male: $n=9$ ) and a focal group consisting of ten women (10 employee- 2 single and 8 married age $=34$ ) were interviewed. Their level of education was as follows: 16 experts (PhD: $\mathrm{n}=14$, Doctor: $\mathrm{n}=1$, Masters: $\mathrm{n}=1$ ), focal group (PhD: $\mathrm{n}=2$, Masters: $\mathrm{n}=8$ ) Interviews took 32 to 113 minutes (with a time average of 72 minutes) and were conducted in the second half of 2017.

Table 1 shows Characteristics of the interviewees.

Statistical Analysis. The data were analyzed using MAXQDA10 software. Data analysis started after the first steps of data collection began using an editorial approach, namely Grounded theory. Then, the data collection and analysis were conducted using the obtained perspectives and thoughts. In this regard, after each interview, issues were implemented and coded openly, axially, and selectively.

For determining the concepts, in fact, the open coding in which basic concepts and classes are formed was used (16). All the interviews were implemented and then coded to transcribe the data collected in the interviews, then open codes were created by line by line and paragraph by paragraph analysis of the existing transcripts. The codes were an adaptation of transcriptions and, sometimes, the same transcriptions. After analyzing the collected data, 1254 initial codes or open codes were extracted. Axial coding is the second step in the analysis of grounded theory; the codes produced in the previous step were rewritten in a new way with the aim of creating a relationship between codes. Axial coding results in the creation of groups and categories; all the similar codes were located in their specific group. In doing so, all created codes were reviewed and compared with the texts so that nothing is omitted. In this process, it was possible for several open codes to be coded as an axial code. The initial classification of codes was divided into 51 subcategories, which were, in turn, categorized into 22 categories in the next step. Selective coding stage, when coding all data by open and axial coding, it was time to group them together; Selective coding based on the results of the two previous coding steps is the main step of grounded theory. Here, the axial class systematically connects to other classes and presents the relationships in a narrative framework and reforms the classes that require more improvement and development. By grouping the codes, the axial codes extracted from the interviews are grouped and then the emerging groups are compared so that the main groups and aspects of each code are recognized and derived. The obtained concepts were ultimately classified into 8 major categories.

Axial coding and Selective coding has been shown at table3. In order to confirm the scientific accuracy of the present study, the accuracy of the data was evaluated. 1. Credibility: In order to achieve this criterion, three different methods were used: data source (we tried to use various resources by selecting the samples from among various executive and academic classes who have knowledge in women's recreational activities, with the confirmation of the research team), a variety of 
methods (multiple methods from interviewing to taking notes were used during the research to maximize data collection procedure), and several analysts (the data analysis process was performed by two coders). 2. Dependability: In this study, to satisfy the criterion of verification, all stages of the research, especially the data analysis, were documented in a detailed comprehensive way, so that if another researcher wanted to continue research in this area, they would be able to easily follow the literature and documentation related to the interviews, analyses, and other research steps. 3. Transferability: In this research, we tried to provide deep and analytical descriptions of the context of the study and a maximum nonrepetitive extraction of this section via reviewing the interview multiple times. 4. Trustworthiness: In the present research, trustworthiness, which means the stability and reliability of data over time and under similar conditions, was obtained through step-by-step repetition and measurement. In order for the interviews to be reliable, re-test and confirmation methods (coded by 2 coders) were used, in both of which the level of consistency was more than $60 \%$; thus, the reliability was confirmed.

Table 1. Characteristics of the interviewees

\begin{tabular}{|c|c|c|c|c|c|c|c|c|c|}
\hline 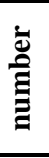 & $\begin{array}{l}\text { Occupational and } \\
\text { social status }\end{array}$ & gender & education & $\begin{array}{l}\text { Time of } \\
\text { the } \\
\text { interview } \\
(\mathrm{min})\end{array}$ & $\frac{\dot{\bar{\Xi}}}{\grave{\Xi}}$ & $\begin{array}{l}\text { Occupational and } \\
\text { social status }\end{array}$ & gender & education & $\begin{array}{c}\text { Time of } \\
\text { the } \\
\text { interview } \\
\text { (min) }\end{array}$ \\
\hline 1 & $\begin{array}{c}\text { Member of the } \\
\text { faculty and } \\
\text { executive member } \\
\text { of the federation }\end{array}$ & female & Ph.D. & 85 & 10 & $\begin{array}{l}\text { Member of the } \\
\text { faculty }\end{array}$ & female & Ph.D. & 70 \\
\hline 2 & $\begin{array}{l}\text { Executive Director } \\
\text { of the rural } \\
\text { federation and } \\
\text { local-native games }\end{array}$ & male & $\begin{array}{l}\text { Ph.D. } \\
\text { student }\end{array}$ & 76 & 11 & $\begin{array}{c}\text { Executive } \\
\text { Director of the } \\
\text { rural federation } \\
\text { and local-native } \\
\text { games } \\
\end{array}$ & male & $\begin{array}{l}\text { Ph.D. } \\
\text { student }\end{array}$ & 80 \\
\hline 3 & $\begin{array}{l}\text { Executive Director } \\
\text { of sport-for-all } \\
\text { federation }\end{array}$ & male & Ph.D. & 73 & 12 & $\begin{array}{l}\text { Member of the } \\
\text { faculty and } \\
\text { executive member } \\
\text { of the federation }\end{array}$ & male & Ph.D. & 33 \\
\hline 4 & $\begin{array}{c}\text { Executive Director } \\
\text { of sport-for-all } \\
\text { federation }\end{array}$ & male & Doctor & 113 & 13 & $\begin{array}{l}\text { Ph.D. graduate in } \\
\text { the relevant field }\end{array}$ & male & Ph.D. & 84 \\
\hline 5 & $\begin{array}{c}\text { member of faculty } \\
\text { and executive } \\
\text { member of } \\
\text { university }\end{array}$ & female & Ph.D. & 60 & 14 & $\begin{array}{l}\text { Ph.D. graduate in } \\
\text { the relevant field }\end{array}$ & female & Ph.D. & 32 \\
\hline 6 & $\begin{array}{l}\text { member of faculty, } \\
\text { executive member } \\
\text { of university and a } \\
\text { member of sport- } \\
\text { for-all federation }\end{array}$ & female & Ph.D. & 79 & 15 & $\begin{array}{c}\text { Executive } \\
\text { Director of the } \\
\text { rural federation } \\
\text { and local-native } \\
\text { games } \\
\end{array}$ & female & M.A. & 60 \\
\hline 7 & $\begin{array}{c}\text { member of faculty } \\
\text { and executive } \\
\text { member of } \\
\text { university }\end{array}$ & male & Ph.D. & 47 & 16 & $\begin{array}{l}\text { Member of the } \\
\text { faculty }\end{array}$ & male & Ph.D. & 32 \\
\hline 8 & $\begin{array}{l}\text { Member of the } \\
\text { faculty and } \\
\text { executive member } \\
\text { of the federation }\end{array}$ & male & Ph.D. & 73 & 17 & $\begin{array}{l}\text { Canon group (5 } \\
\text { university } \\
\text { employees and } 1 \\
\text { sessional }\end{array}$ & female & M.A. & 90 \\
\hline 9 & $\begin{array}{l}\text { Sports organization } \\
\text { executive director }\end{array}$ & female & $\begin{array}{l}\text { Ph.D. } \\
\text { student }\end{array}$ & 54 & & $\begin{array}{c}\text { university } \\
\text { instructor) }\end{array}$ & & & \\
\hline
\end{tabular}

\section{RESULTS}


In this research, the contextual conditions were considered in the case of Iranian women's recreational activities. The results identified socio-cultural, fundamentals of Islam, political issues, economic issues, macroeconomic, and geographical environment issues as the main factors.

Table 2. The examples of open coding

\begin{tabular}{|c|c|c|}
\hline Sentence & Interpretation & Extracted code \\
\hline $\begin{array}{l}\text { The state of women's sports is not good at all } \\
\text { because of our cultural issues! The cultural aspect of } \\
\text { this issue is greater than anything else, because there } \\
\text { is gender discrimination in all societies! In some } \\
\text { societies, such as African societies, hegemony is } \\
\text { more prevalent, but in more advanced societies, at } \\
\text { least, they try to conceal this issue, yet these } \\
\text { differences exist, although not so much as those of } \\
\text { the eastern communities such as Iran, Saudi Arabia, } \\
\text { and By taking a look at the statistics, gender } \\
\text { discrimination is more common in the Middle East. } \\
\text { The Middle East is the center of Islam and the } \\
\text { majority of the discrimination can be observed in } \\
\text { Arab societies, in which woman is used as a tool, } \\
\text { which I think is against the nature of Islam! For } \\
\text { instance, in such societies, women cannot exercise } \\
\text { in public and such things. }\end{array}$ & $\begin{array}{l}\text { Undesirability of women's sports } \\
\text { condition -gender discrimination in the } \\
\text { world-greater gender inequality in } \\
\text { eastern and Muslim societies -using } \\
\text { women as tools-misuse of Islam- } \\
\text { Muslim women facing sports } \\
\text { constraints }\end{array}$ & $\begin{array}{l}\text { Gender as an } \\
\text { effective factor in } \\
\text { participation in sports } \\
\text { Gender } \\
\text { discrimination in the } \\
\text { world- } \\
\text { Women's limitations } \\
\text { in Islamic countries- } \\
\text { Hegemony against } \\
\text { women } \\
\text { Misuse of Islam }\end{array}$ \\
\hline $\begin{array}{l}\text { The urban planning and urban furniture of our cities } \\
\text { have never been in accordance with recreational } \\
\text { sports and our physical activities. This is because it } \\
\text { has not been a priority for the municipality, thus less } \\
\text { paid attention to. We should expand open and free } \\
\text { spaces, it can help women's recreational activities. } \\
\text { There is a plan for them in other countries, but not } \\
\text { us! Enough open spaces and sport facilities have not } \\
\text { been allocated to the cities, towns, residential } \\
\text { complexes, suburb campuses and Mehr apartments, } \\
\text { and accessibility to them is limited. It is essential that } \\
\text { the standards be met so that the possibility of sports } \\
\text { activities is provided for people. }\end{array}$ & $\begin{array}{l}\text { Incompatibility of urban planning and } \\
\text { urban furniture with recreational sports } \\
\text { and physical activities -sports not } \\
\text { being a priority in city planning - } \\
\text { Increased open spaces leading to the } \\
\text { expansion of recreational sports - } \\
\text { Restricted access to green spaces and } \\
\text { facilities }\end{array}$ & $\begin{array}{l}\text { Incompatibility of } \\
\text { urban planning with } \\
\text { recreational sports } \\
\text { and physical } \\
\text { activities- } \\
\text { Increasing open } \\
\text { spaces leads to the } \\
\text { increased } \\
\text { participation } \\
\text { women- } \\
\text { Easy access to green } \\
\text { spaces }\end{array}$ \\
\hline
\end{tabular}

\section{DISCUSSION}

The categories are described below: Sociocultural issues: According to the findings of this research, socio-cultural stereotypes are the result of family, society, and school upbringing and form the basis of social culture. These stereotypes are the result of beliefs and values and root in the past. Considering the wide variety of ethnic groups and cultures in different parts of the country as well as the existence of cultural differences in villages and cities, a long-term program to build the culture of women's recreational sports is needed. In this regard, it is necessary to build the culture in educational institutions to train various age groups. In line with general culture-building in our country and considering the cultural diversity of the ethnic groups in different regions and the various social issues that women in villages, towns, and cities face, it is essential that leisure activities be planed according to different conditions so that women can be more active in the current society. Physical education organizations and municipalities are responsible for planning this crucial issue, which, considering the cultural rules governing the country, leads to a more participation of women in sports activities. In various studies, the negative impact of socio-cultural issues on women's participation in sports over time has 
been confirmed. In the research done by Mirghafoori's (2009) socio-cultural issues was recognized as one of the most important barriers to the progress of Iranian women (19). In a study conducted by Sawrikar (2010), Hindi women and other ethnic minorities, compared to Australian women, had equal access to the same to facilities, but they did not have the same opportunity to participate in sports and recreational activities due to socio-cultural deprivation (20). Similarly, Anaza (2013), who investigated the constraints urban Nigerian women encounter when participating in leisure and sports activities, introduced cultural barriers as one of the obstacles urban Nigerian women face when they want to participate in recreational sports activities (6). According to the results of domestic studies, the other types of cultural barriers include patriarchal culture in the Iranian society (19), patriarchal culture in the sports community, the fear of staying out of home, worrying about other people's negative attitudes, the disturbance made by stranger men while women go out, and viewpoints regarding the negative effects of sports on women's appearance (19). Atghia (2007) mentioned lack of proper culture-building plans among Iranian women regarding the importance of sports activities. Results of this study also confirm all of the above-mentioned points (21).

Table 3. Axial coding \& Selective coding

\begin{tabular}{|c|c|c|c|c|}
\hline \multirow{2}{*}{ number } & \multicolumn{2}{|l|}{ Axial coding } & \multirow{2}{*}{ Selective coding } & \multirow{2}{*}{ number } \\
\hline & subcategory & category & & \\
\hline 1 & Economic issues & Economic issues & Economic issues & 1 \\
\hline 2 & Authorities' demands & \multirow{3}{*}{$\begin{array}{l}\text { the current governing } \\
\text { atmosphere }\end{array}$} & \multirow{18}{*}{ macromanagement } & \multirow{18}{*}{2} \\
\hline 3 & City management & & & \\
\hline 4 & Organization's disregard for sport & & & \\
\hline 5 & Optimization & \multirow{2}{*}{ Integrated Management } & & \\
\hline 6 & management integration & & & \\
\hline 7 & $\begin{array}{l}\text { Current condition of the management } \\
\text { of women in Iran }\end{array}$ & $\begin{array}{l}\text { Management opportunity } \\
\text { for women }\end{array}$ & & \\
\hline 8 & competency & meritocracy & & \\
\hline 9 & Organizational Culture & \multirow{4}{*}{ Organizational Culture } & & \\
\hline 10 & $\begin{array}{c}\text { Operationalization of sports in } \\
\text { organizations }\end{array}$ & & & \\
\hline 11 & $\begin{array}{l}\text { Lack of communication between } \\
\text { organizations }\end{array}$ & & & \\
\hline 12 & Administrative system conditions & & & \\
\hline 13 & Organizational Performance Index & The criterion of & & \\
\hline 14 & The weakness of current structures & performance & & \\
\hline 15 & Management of women in sports & \multirow{5}{*}{ managing sports } & & \\
\hline 16 & Women as Deputy chairmen & & & \\
\hline 17 & $\begin{array}{l}\text { The patriarchal atmosphere governing } \\
\text { sport management }\end{array}$ & & & \\
\hline 18 & Weakness in managing sports & & & \\
\hline 19 & Human resources management & & & \\
\hline 20 & Misuse of Islam & \multirow{4}{*}{ Fundamentals of Islam } & \multirow{4}{*}{$\begin{array}{l}\text { Fundamentals of } \\
\text { Islam }\end{array}$} & \multirow{4}{*}{3} \\
\hline 21 & The rules of Islam & & & \\
\hline 22 & references & & & \\
\hline 23 & hijab & & & \\
\hline 24 & Social culture & \multirow{6}{*}{ Social culture } & \multirow{6}{*}{ Socio-cultural issues } & \multirow{6}{*}{4} \\
\hline 25 & Social values & & & \\
\hline 26 & Patriarchal System & & & \\
\hline 27 & Social cultural stereotypes & & & \\
\hline 28 & Features of different regions of Iran & & & \\
\hline 29 & Leisure activities proper for rural areas & & & \\
\hline
\end{tabular}


Table 3. Continued

\begin{tabular}{|c|c|c|c|c|}
\hline 30 & Culture-building in Educational Institutions & General public building & & \\
\hline 31 & Social damages & \multirow{2}{*}{ Social issues } & & \\
\hline 32 & Social barriers & & & \\
\hline 33 & International issues & \multirow{2}{*}{ International issues } & \multirow{4}{*}{ Political issues } & \multirow{4}{*}{5} \\
\hline 34 & Islamic countries & & & \\
\hline 35 & Domestic political issues & \multirow{2}{*}{ Domestic political } & & \\
\hline 36 & Governmental restrictions & & & \\
\hline 37 & various climatic features & Geographical & \multirow{3}{*}{$\begin{array}{l}\text { Geographical } \\
\text { Environment }\end{array}$} & \multirow{3}{*}{6} \\
\hline 38 & Spatial planning & environment & & \\
\hline 39 & the environment & environment & & \\
\hline 40 & The importance of advertising & \multirow{3}{*}{ advertising } & \multirow{8}{*}{ Media and advertising } & \multirow{8}{*}{7} \\
\hline 41 & Advertising Impact in the presence of women & & & \\
\hline 42 & The positive effect of displaying sports models & & & \\
\hline 43 & Notification system & Notification & & \\
\hline 44 & Media and women & \multirow{4}{*}{ media } & & \\
\hline 45 & Media format & & & \\
\hline 46 & The Role of Media in the Society & & & \\
\hline 47 & Media and cartoons & & & \\
\hline 48 & Equipment and facilities & \multirow{2}{*}{ Sports facilities } & \multirow{4}{*}{ Sports facilities } & \multirow{4}{*}{8} \\
\hline 49 & Sports environments & & & \\
\hline 50 & $\begin{array}{l}\text { providing Facilities in universities in accordance } \\
\text { with genders }\end{array}$ & Gender Equality & & \\
\hline 51 & easy access & easy access & & \\
\hline
\end{tabular}

P8: "The reason behind all of the differences between men and women is gender-related beliefs, for example, women's IQ is less than men's, a theory which was rejected after scientific studies. These ideas and beliefs of gender are merely cultural perspectives. Scientists who are against gender distinction provided different theories, for instance, after the sex of the baby is determined, parents buy clothes and toys for which is traditionally used for that gender, for example, they buy cars for boys and dolls for girls".

P13:"It can be said that nearly 90 percent of the differences are a product of family and education community. There is a heavy patriarchal perspective in the country. Therefore, despite the existence of differences all over the world, it is bolder and more intense in our country, which affects the participation of women."

Fundamentals of Islam: In our Islamic society, there are issues of religion and its fundamentals. The results of this research confirm the fact that, despite Islam's emphasis on joy, health, and exercise in society, its rules have been used based on whim that had an impact on the presence of women in recreational sports and their views. This is especially true in smaller regions, where cultural issues are so intertwined with religious beliefs that many of the constraints which are the product of culture are viewed in line with religious beliefs; thus, women who do sports end up being reprimanded. It is worthy to mention that Hijab is one of the requirements of Islam and needs to be observed when recreational sports are done in open and mixed-sex environments. However, Hijab brings about limitations in sports for individuals; therefore, a culture of sports must be built among women so that they do not think of hijab as a barrier to sports and view it as tone of their life necessities. Experts believe that references' support of sports can greatly promote sports among women in society. In various studies, the effect of this factor as one of the obstacles to the development of recreational sports has been emphasized. For instance, Mirghafoori (2009) mentioned fear of harming religious beliefs (19), while Lenneis (2017) introduced the lack of experiences in sports and leisure activities and living environment as an imitating factor for women's participation in recreational sports (22). According to this research, Islam has no explanation for the lack of participation in recreational sports. In our 
religion, sports is strongly and frequently suggested for men and women. For instance, Imam Ali $(\mathrm{PBUH})$, quoting the holy prophet $(\mathrm{PBUH})$, states that: "Teach archery and swimming to your children" (23).

P15:"Gender discrimination exists in all societies. In some societies, such as African societies, there is more hegemony, but in more advanced societies, these issues are at least attempted to be concealed in the society. Yet, there are differences, but not as much as those in Eastern Muslim societies like Iran, Saudi Arabia."

P14:"There are various interpretations in relation to the Islamic conditions, for example, some interpret that there are no constraints for women, whereas some believe that restrictions are imposed on women. A researcher named Sadegh Aeini Vand has interpreted original Islamic texts and rejected what is defined as a constraint by referring to the texts. As a matter of fact, these people are exactly the ones who give freedom to women whenever they wish and take it from them as they fancy! In my opinion, considering maintaining certain Islamic frameworks, it is better to provide a condition in which no harm is done to women's sports and leisure activities, while Islamic rules are being observed simultaneously."

Economic issues are important issues that affect citizens' participation in sports $(24,25)$ which, are of high priority, particularly in our developing country. The results of this study indicate that economic problems of the country, families' low incomes, life expenses, and expenses related to the use of sports facilities are all among the issues that affect women recreational sports. Although several types of recreational activities can be done with the least amount of cost and facilities, most interviewees believed families' economic issues and life problems prevent families from doing sports. In fact, these problems cause people to work harder due to difficult conditions of life, which leads to more mental conflicts; thus, they try to use their income to meet the basic needs of the family and do not pay attention to the quality of their leisure time.

In line with other research findings, Eime (2015) emphasized the role of socioeconomic conditions in sports participation. Various studies concluded that economic factors as well as economic class of individuals and their income have been effective in recreational activities of women in the country (26). According to these researchers, the lack and expensiveness of women's sports facilities (21), economic conditions of families, the high cost of participation in women's sports activities (19), and low income and financial constraints (24) affect women's sports activities in all ages and are considered as obstacles to women's participation in recreational sports.

P6:"Families' economic condition is a matter of great concern! A mother who worries about providing food for her children is not concerned about sports and does not spend money on it."

P7:"A significant number of the factors influencing people's participation in sports activities in society are the results of economic issues. Say, why, for example, insurance companies do not cooperate with pool facilities and, in specific times, allow people with insurance to get a discount in the pool facilities. In this way, on the one hand, people do more exercising activities because of the discount. On the other hand, disease prevention is done and the costs that the insurance company has to pay for the discount are considerably less than treatment costs need to be paid in the future."

Political Issues: According to the results of this research, the political changes in the country have an impact on the sports in the society. For example, the country's political relations and international economic sanctions against Iran affect the budget and the costs spent on recreational sports. Besides, attitudes of politicians toward recreational sports, especially women's recreational sports, affect the condition of women's sports in society, the type of costs spent on women's sports, funds allocated to them, the choice managers of sports organizations, etc. This can, in turn, affect the development of women's recreational activities. Hence, a legal requirement to support recreational sports at executive levels and the transition of decisionmakers from theory to practice regarding issues related to women is absolutely essential. Brownson (2001) also believed that political and environmental factors affect physical activities in the United States (25). In respect to the importance of this issue in the national framework for expanding sports in England, political issues are put into this framework $(25,27)$.

P1:"Due to the great number of problems and the lack of infrastructures in our country, various economic and political changes in the society have led to marginalization of women's sports."

P8:"A point which needs to be stated is that, along with other issues existing in the country, decision-makers do not very much concern 
themselves with women's sports because there are, for example, other issues such as sanctions and economic problems, among which women's sports do not seem important."

Macro-management: The results of this study indicate that there is a patriarchal system governing the country, especially in terms of sports management. This has prevented meritocracy from taking place and, consequently, a resistance to the presence of women at high levels of management has occurred. However, in order for an all-round development of women's issues to happen, particularly a development in sports' issues, the presence of female managers is crucial. According to the majority of experts, deputy chairwomen in federations have a ceremonial position and do not possess any powers in decision making. The existence of multiple decision-making organizations in the country and independent managements in different organizations are among other detrimental factors which lead to the waste of great amount of money and energy without achieving the desired results. Integrated management of sport leads to an all-out development of sports in which the desired results can be achieved through proper planning of budgets. Many infrastructures and facilities available in different organizations have the potential to be used efficiently, while the separation of managements leads to a lack of overlaps among various needs of the society in the field recreational sports. This has led the facilities and infrastructures to be limitedly available to special organizations and institutions, rather than being efficiently used to improve the health and joy of the society. However, if every organization plans sports programs for its employees and their families with regard to its potentials, the majority of population in the society can be benefited by recreational activities and services.

Experts believe that organizational culture is built in a way that managers don't care about the recreational sports of their employees and their families. There has never been any law requiring the staff to exercise in which case the managers have freedom in making decisions. Managers who are aware of the important role of sport and its positive effects on their employees' performance use the budget of the organization's sports sector to involve the staff in sports. Unfortunately, not all managers have this viewpoint. Thus, the organization's sports budget is often not used to promote and institutionalize sports among employees and, rather than being used to attract more female employees to sports, it is merely spent on providing some exercise equipment or on the preparation of the office's sports team for special occasions (mostly for men). The current administrative systems and women's working hours require managers to pay attention to the health of female employees by considering appropriate subsidies, which can lead to an increase in the efficiency of the organization and an improvement in its performance. Experts believe that if the tendency of an organization in involving employees in recreational sports is considered a criterion for evaluating the performance of organizations and if organizations are required to submit an annual report on the female employees' sports activities, employees' sports activities will be deemed as important; thus, they will be implemented.

Urban management is another issue that affects the physical activity of citizens. According to experts, our urban texture and urban furniture is not consistent with the principles of physical activity and sidewalks in our country are not suitable for pedestrians of various conditions (old, child, disabled people, etc). Elimination of technical problems in urban furniture creates a sense of lack of movement.

In different studies, which were consistent with the results of this study, management issues have been identified as effective factors in the recreational activities of women in Iran. Mirghafoori (2009) viewed authorities' lack of attention to women' sports in society as a barrier leading to the low participation of women in sports (19).

P11:"There are problems with the laws. The law allows an employee to spend 4 hours exercising only if the boss deems it appropriate. The boss usually does not deem it appropriate at all. He makes such decisions based on his personal views, so we have problems with law enforcement."

P12:"We don't have the support of the society, for example, at the time of the revolution, women worked as much as men. Why don't we have a female minister now?! Why aren't there any female managers at top levels?! That's why patriarchal views run the country!!"

Geographical environment: Regarding geographical environment, the results of this research confirm that while dealing with the sports issues of the country, expert don't give much 
attention to spatial planning and climate differences. Infrastructures and facilities are not distributed according to the population and conditions and there is no proper planning to help urban and rural areas have access to facilities appropriate to their population. On the other hand, the cultures of different regions require plans for each particular region, which is consistent with its ethnic and local characteristics and provides conditions for the presence of women in recreational sports. Climate difference in our country is an opportunity for managers to take advantage of promoting recreational sports in each region. Due to the greater acceptance of proper sports, this increases the tendency of individuals, especially women, to participate. Protecting the environment and developing this perspective through recreational activities also needs to be taken into account. For example, considering walking and cycling conditions (proper sidewalks and walking paths) in planning the urban furniture or people's willingness in walking and their less usage of personal vehicles, are all factors which can help the environment. Increasing green and open spaces to develop recreational sports also makes a great contribution to the protection of the environment. Domestic researches have confirmed the role of geographic and natural environment(28) in the condition of recreational sports in Iran. In the same vein, Solbraa (2018) acknowledged that geographical differences affect Norwegians' amount of physical activity (29).

P10:"Helping and protecting the environment and its development through exercise can be realized. For example, if there were three bus stations instead of five bus stations on a street, we would have helped the environment because of lower carbon dioxide emissions. Also, people would gain more health because of more walking."

P6:"One of the problems we have is that facilities aren't in accordance with different climates of the country and that we don't take advantage of the potentials of different climates in the development of recreational sports."

Media and Advertising: As a powerful tool, media can be very influential in creating a culture of sports in the society. Various studies have confirmed this fact and acknowledged the positive impact of targeted advertising on the tendency of people toward recreational sports $(30,31)$. Besides, the small share of women's sports in television broadcasting over time, despite an increase in their participation, has been emphasized by Cooky
(2015) and Waaneberg (2011) (32,33). In his study, Cooky (2015) he investigated the coverage of women's sports in television' sports news in three local news agencies in Los Angeles for 6 weeks and concluded that the level and quality of women's sports coverage were at the lowest level and that women's sports news were overshadowed and marginalized by men's (32). In addition, women's sports in the foreign media, for the most part, are aimed at presenting women as goods and for the purpose of showing a healthy body, while, in case of men, only performance is focused (34).

The results of this research confirm the abovementioned fact. Media, television in particular, are strongly biased in relation to women's sports, whether in recreational sports or in championship, and male hegemony is dominating sports programs and news. These common mindsets ruling the media lawmakers prevents them from following correct paths; thus, the media does not fulfill its responsibility toward the health of the women in the society compromising half of the country's population and toward building the culture of this important issue. It is necessary to promote the culture through advertising women's sports in public places (media, parks, city buses, etc), modeling successful sports women in the media, using them in advertising, showing sports programs about women, and covering women's sports in both recreational and championship sports at the times when most people watch. Cartoons and children and adolescents' programs are effective factors in the development of the culture, since they directly affect the mindset of the audience. The number of cartoons in the national media which focus on sports is small, despite the fact that it can highly contribute to promoting the culture of recreational sports.

P15:"One of the most important obstacles that prevents the proper development of our women's sports is the media. The fault in our media is twofold. First, instead of organizations, the media does the thinking, while organizations must make requests in this regard. Second, there are restrictive laws that prevent the representation women's sports in media from being effective and attractive. For example, the cameramen don't get a close-up shot while filming women's volleyball games. Even in the press and in newspapers, photographs of women either are taken from very far away or are shown in formal clothes! Just like television."

P13:"There are other factors such as a patriarchal outlook. More often than not, Sports planners are 
men; therefore, they don't understand the needs of women properly. There are feminine tastes that should be reflected while representing women's sport in order to make them attractive. There should be a sponsors' section in the field of women's sports, which does not currently exist. There are absolutely no analytical programs for women's sports right now. In the programs, the analysts are usually men, and if there are any women, they often say a sentence or two and men do most of the analysis."

Sports Facilities: According to previous studies, sports facilities are among the factors affecting the level of women's participation in recreational sports in different countries $(8,15,24$, $35)$. In various studies, the lack of equipment and facilities has been mentioned as the most important reason as to why women do not exercise in our country. The factors related to the facilities include lack of access to proper sports halls and gyms suitable for women, expensiveness and lack of exercise equipment for women, unsuitable time schedules of gyms (19), lack of investment in the development of women's sports facilities (11), lack of facilities for women (21).

In addition to acknowledging the abovementioned facts, the findings of this study confirm that justice is not observed in regard to men and women's access to sports facilities and infrastructures, in spite of the fact that access to sports halls, regardless of the socioeconomic conditions of individuals, strongly influences their sports activity pattern (36). In terms of quality, the best times and facilities are available for men. Usually, the times available for women coincide with working hours and given the employment of women nowadays, it isn't possible for this large population to use those facilities. The same is the case in university environments. Despite the greater number of females in universities, the quality of facilities for women is lower.

P5:"There are weaknesses in the distribution of resources in our country. The lack of proper distribution of equipment, infrastructure, manpower, and Resources in our country is a huge weakness which prevents the development of sports."

P8:"In countries like Sweden, Norway, Finland and Denmark, the government has expanded sports facilities and places where people can exercise, this has caused men and women, who have free access to facilities and are willing to participate in sports, to highly participate in sports. This will create motivation in other people and induce them to start exercising. Despite the fact that winter lasts for 9 months in these countries, people include exercises such as stretching in their daily lives."

\section{CONCLUSION}

The aim of this research was to determine the contextual conditions of Iranian women's recreational sport. The researcher reached theoretical saturation after conducting 17 interviews. The data were analyzed by used of MAXQDA10 software 1254 initial or open codes has extracted after analyzing the interviews. In the stage of axial coding, the initial codes classified into 22 groups and finally the 8 main group has extracted in the stage of selected coding. The eight major categories include of socio-cultural, fundamentals of Islam, political, economic, geographical environments and macro-management, media and advertisement, and sports facility issues. Understanding these factors helps sports managers to plan and accurately identify women's sports fields with specific features of Iranian Muslim women. In this context, reducing the existing weaknesses and deficiencies to provide more recreational sports development. These information let to achieve the goals of women's recreational sports. One of the limitations of this research was the diversity and wide variation of Iranian women's conditions in different regions of the country. This calls for local women's expertise to be explored by local administrators.

\section{APPLICABLE REMARKS}

- Drafting a by-law for the national division of labor in order to divide labor among sports organizations", "facilitating sports fields in accordance with different age groups", "designing supportive laws and providing subsidies for women and women's sports", "promoting the culture of recreational sports and showing women's sports news and events through audiovisual media, particularly television, and advertising women's sports in public places (media, parks, city buses, etc). 


\section{REFERENCES}

1. Torkildsen G. Torkildsen's sport and leisure management: Routledge; 2012.

2. O'Sullivan E. Power, promise, potential, and possibilities of parks, recreation, and leisure. Introduction to recreation and leisure. 2006:3-16.

3. Ross C. Recreational sport management. Introduction to recreation and leisure. 2006:271-88.

4. Carr K, Smith K, Weir P, Horton S. Sport, Physical Activity, and Aging: Are We on the Right Track? Sport and Physical Activity across the Lifespan: Springer; 2018. p. 317-46.

5. Swann C, Telenta J, Draper G, Liddle S, Fogarty A, Hurley D, et al. Youth sport as a context for supporting mental health: Adolescent male perspectives. Psychology of sport and exercise. 2018;35:55-64. [DOI:10.1016/j.psychsport.2017.11.008]

6. Anaza E, McDowell J. An investigation of constraints restricting urban Nigerian women from participating in recreational sport activities. Journal of Leisure Research. 2013;45(3):324-44. [DOI:10.18666/jlr-2013-v45-i33154]

7. Al-Eisa ES, Al-Sobayel HI. Physical activity and health beliefs among Saudi women. Journal of nutrition and metabolism. 2012;2012.

8. Huang H, Humphreys BR. Sports participation and happiness: Evidence from US microdata. Journal of economic Psychology. 2012;33(4):776-93. [DOI:10.1016/j.joep.2012.02.007]

9. Barnett F, Spinks WL. Exercise self-efficacy of postmenopausal women resident in the tropics. Maturitas. 2007;58(1):1-6. [DOI:10.1016/j.maturitas.2007.04.003] [PMID]

10. Gollschewski S, Kitto S, Anderson D, Lyons-Wall P. Women's perceptions and beliefs about the use of complementary and alternative medicines during menopause. Complementary therapies in medicine. 2008;16(3):163-8. [DOI:10.1016/j.ctim.2007.06.001] [PMID]

11. Mutmani A, Hemmati A, Moradi H. Identifying and prioritizing obstacles facing women in sports activities. Sports Management Studies Journal. 2014(24):111-30.

12. Nategh A, Malek A, Sadegh H, Davoud A. Women Physical Activity and its Effective Factors Using a SocialEcological Model. Annals of Medical and Health Sciences Research. 2017.

13. Mu-iz C, Rodríguez P, Suárez MJ. Sports and cultural habits by gender: An application using count data models. Economic Modelling. 2014;36:288-97. [DOI:10.1016/j.econmod.2013.09.053]

14. Toffoletti K, Palmer C. New approaches for studies of Muslim women and sport. International Review for the Sociology of Sport. 2017;52(2):146-63. [DOI:10.1177/1012690215589326]

15. El Gilany A, Badawi K, El Khawaga G, Awadalla N. Physical activity profile of students in Mansoura University, Egypt. 2011.

16. Corbin J, Strauss A. Basics of qualitative research: Techniques and procedures for developing grounded theory. 2008.

17. Denzin NK, Lincoln YS. Handbook of qualitative research: Sage publications, inc; 1994. [PMID]

18. Neergaard MA, Olesen F, Andersen RS, Sondergaard J. Qualitative description-the poor cousin of health research? BMC medical research methodology. 2009;9(1):52. [DOI:10.1186/1471-2288-9-52] [PMID] [PMCID]

19. Mirghafoori H, Sayyadi Touranlou H, Mirfakhreddini SH. The Analysis of Factors Affecting Women's Participation in Sport (Female Students of Yazd University). Journal of Sport Management. 2009;1(1):83-100.

20. Sawrikar P, Muir K. myth of a 'fair go': Barriers to sport and recreational participation among Indian and other ethnic minority women in Australia. Sport Management Review 2010;13:355-67. [DOI:10.1016/j.smr.2010.01.005]

21. Atghya N. Needs Assessment of Different Groups of Iranian Women in General Sports Research in Sport Sciences. 2007;17(5):15-31.

22. Lenneis V, Pfister G. When girls have no opportunities and women have neither time nor energy: the participation of Muslim female cleaners in recreational physical activity. Sport in Society. 2017;20(9):1203-22. [DOI:10.1080/17430437.2016.1269085]

23. Al-Kulayni MY. Al-Kāfì. Qom: Daroalhadis; 2008. 47 p.

24. Cheah Y. Influence of socio-demographic factors on physical activity participation in a sample of adults in Penang, Malaysia. Malaysian journal of nutrition. 2011;17(3). [PMID]

25. Brownson RC, Baker EA, Housemann RA, Brennan LK, Bacak SJ. Environmental and policy determinants of physical activity in the United States. American journal of public health. 2001;91(12):1995-2003. [DOI:10.2105/AJPH.91.12.1995] [PMID] [PMCID]

26. Eime RM, Charity MJ, Harvey JT, Payne WR. Participation in sport and physical activity: associations with socioeconomic status and geographical remoteness. BMC public health. 2015;15(1):434. [DOI:10.1186/s12889-0151796-0] [PMID] [PMCID] 
27. Sport England. The framework for sport in England: Making England an active and successful sporting nation: A vision for 2020: Sport England; 2004.

28. Safari M, Ghareh MA. Identification and Classification of Effective Environmental Factors in Popularity of Recreational Sports in Iran. Journal of Sport Management. 2016;8(1):51-68.

29. Solbraa AK, Anderssen SA, Holme IM, Kolle E, Hansen BH, Ashe MC. The built environment correlates of objectively measured physical activity in Norwegian adults: A cross-sectional study. Journal of Sport and Health Science. 2018;7(1):19-26. [DOI:10.1016/j.jshs.2017.11.002] [PMID] [PMCID]

30. Miles A, Rapoport L, Wardle J, Afuape T, Duman M. Using the mass-media to target obesity: an analysis of the characteristics and reported behaviour change of participants in the BBC'sFighting Fat, Fighting Fit'campaign. Health Education Research. 2001;16(3):357-72. [DOI:10.1093/her/16.3.357] [PMID]

31. Vann P. Changing the game: The role of social media in overcoming old media's attention deficit toward women's sport. Journal of Broadcasting \& Electronic Media. 2014;58(3):438-55. [DOI:10.1080/08838151.2014.935850]

32. Cooky C, Messner MA, Musto M. "It's dude time!" A quarter century of excluding women's sports in televised news and highlight shows. Communication \& Sport. 2015;3(3):261-87. [DOI:10.1177/2167479515588761]

33. Wanneberg PL. The sexualization of sport: A gender analysis of Swedish elite sport from 1967 to the present day. European Journal of Women's Studies. 2011;18(3):265-78. [DOI:10.1177/1350506811406075]

34. Romero E, Pereira EGB, Miragaya AMdF, Sant'Anna KBS. Mulheres na imprensa esportiva: imagens e palavras. Salusvita. 2014;33(3).

35. Hallman K, editor Individual and infrastructural determinants of participation in different sports. 19th Conference of the European Association for Sport Management Dostupno na:[ http://www.easm2009.com/]; 2011.

36. Wicker P, Breuer C, Pawlowski T. Promoting sport for all to age-specific target groups: the impact of sport infrastructure. European sport management quarterly. 2009;9(2):103-18. [DOI:10.1080/16184740802571377] 